\title{
Strategi Pengelolaan Sumber Daya Alam Kawasan Perdesaan Berbasis Perikanan di Kabupaten Gresik dan Tuban
}

\author{
Faqih Alfian \\ Program Studi Ilmu Politik Universitas Brawijaya \\ Email: alfaqih99@ub.ac.id \\ Taufik Akbar \\ Program Studi Ilmu Politik Universitas Brawijaya \\ Email: takbar@ub.ac.id
}

Naskah diterima: 18 Januari 2020| Naskah disetujui: 18 Februari 2020

\begin{abstract}
The wealth of marine and fisheries resources is very large, contrary to the sadness of the assumptions which are marine and fisheries resources that make fisheries live prosperously, pushed over by data from the Ministry of Maritime Affairs and Fisheries in 2010, it takes 7.87 million poor coastal communities and 2.2 million inhabitants of the coastal population are very poor in all parts of Indonesia. These poor fishermen are scattered in 10,640 fishing villages. This research is aimed to (a) analyzing the level of benefits of government assistance for villages/agriculture-based areas, (b) understanding fisheries-based management models, (c) formulating forms of facilitation activities in rural areas based on fisheries potential. In Gresik and Tuban Regencies, following the 2014 KKP Statistics data from the East Java Province Fisheries and Maritime Services, both regions have some fisheries as well as rural areas with fishery potential. Through observations and analyses from several aspects, in Tuban and Gresik Districts have not felt the influence of assistance from the government. There needs to be assistance to capture the capital, which will have a significant impact on society.
\end{abstract}

Keywords: Natural Resources, Fisheries, Rural area, Coastal area, Policy

\begin{abstract}
Abstrak
Kekayaan sumberdaya kelautan dan perikanan yang sangat besar, bertolak belakang dengan mirisnya kondisi perekonomian nelayan di Indonesia terutama nelayan yang berada di kawasan perdesaan. Asumsi bahwa besarnya sumberdaya kelautan dan perikanan menjadikan nelayan hidup sejahtera, ditepis oleh data Kementerian Kelautan dan Perikanan tahun 2010 menegaskan bahwa terdapat 7,87 juta masyarakat pesisir miskin dan 2,2 juta jiwa penduduk pesisir sangat miskin di seluruh wilayah Indonesia. Nelayan miskin tersebut tersebar di 10.640 desa nelayan di pesisir. Penelitian ini ditujukan untuk (a) menganalisa tingkat kemanfaatan bantuan pemerintah untuk desa/kawasan perdesaan berbasis potensi perikanan, (b) mengetahui model pengelolaan kawasan perdesaan berbasis perikanan, (c) merumuskan bentuk kegiatan fasilitasi pada kawasan perdesaan berbasis potensi perikanan. Fokus penelitian ini pada Kabupaten Gresik dan Kabupaten Tuban, sesuai dengan data Statistik KKP 2014 dari Dinas Perikanan dan Kelautan Provinsi Jawa Timur kedua daerah tersebut
\end{abstract}


memiliki jumlah nelayan maupun kawasan perdesaan dengan potensi perikanan. Dari hasil observasi serta analisis dari beberapa segi, di Kabupaten Tuban dan Gresik belum merasakan dampak adanya bantuan dari pemerintah. Perlu adanya fasilitasi pendanaan atau modal utamanya bagi nelayan tangkap, dimana hal itu nantinya akan berdampak signifikan terhadap masyarakat.

Kata Kunci: Sumber Daya Alam, Perikanan, Kawasan Pedesaan, Kebijakan Pemerintah

\section{Pendahuluan}

Indonesia merupakan negara maritim yang memiliki luas laut sebesar 5.8 juta $\mathrm{km}^{2}$ dengan keanekagaraman sumber daya kelautan dan perikanan yang sangat besar (Bappenas, 2014). Luas wilayah tersebut memiliki potensi produksi ikan laut cukup besar, dengan asumsi sekitar 6.51 juta ton/tahun atau $8.2 \%$ dari total potensi produksi ikan laut dunia (Kepmen KP, 45-2011). Dengan kekayaan laut dan perikanan yang begitu besar, sangat bertolak belakang dengan mirisnya kondisi perekonomian nelayan di Indonesia, terutama nelayan di kawasan perdesaan. Asumsi bahwa besaran sumber daya laut dan perikanan menjadikan nelayan dapat hidup sejahtera ditepis oleh data Kementerian Kelautan dan Perikanan tahun 2010, yang menegaskan bahwa terdapat 7.87 juta masyarakat pesisir miskin dan 2.2 juta jiwa penduduk pesisir sangat miskin tersebar di 10.640 desa nelayan di pesisir.

Presiden Joko Widodo dalam Nawa Cita pilar kedua (Poros Maritim Dunia) menegaskan komitmennya untuk menjaga dan mengelola sumber daya laut dengan fokus membangun kedaulatan pangan laut dengan menempatkan nelayan sebagai pelaku utama melalui pengembangan industri perikanan. Oleh karena itu, komitmen Presiden Joko Widodo terus berupaya untuk mendorong pemerintah pusat/provinsi/daerah untuk meningkatkan kesejahteraan nelayan dan pembangunan pada kawasan perdesaan yang memiliki potensi bidang perikanan.

Sektor perikanan merupakan salah satu faktor strategis yang menggerakkan perekonomian di tingkat desa dan menjadi bagian dari perekonomian Indonesia bila dikelola dan dioptimalkan pemanfaatannya dengan baik. Pengelolaan perikanan yang bertumpu pada otoritas desa menjadi sebuah potensi yang besar dengan berpedoman pada kerangka pembangunan desa: "Tri Matra Pembangunan Desa". Data yang bersumber dari Dinas Perikanan dan Kelautan Provinsi Jawa Timur tahun 2014 mencatat bahwa total 38 kabupaten/kota di Jawa Timur; 22 kabupaten/kota di antaranya memiliki desa yang bersentuhan langsung dengan bidang perikanan baik tangkap 
maupun budidaya. Potensi tersebut menjadikan pengelolaan sumber daya alam di kawasan perdesaan berbasis perikanan perlu didorong dan membutuhkan perhatian yang serius agar dapat meningkatkan kemanfaatan bagi desa.

Konsep dan paradigma baru tentang pengelolaan desa berbasis perikanan yang menerapkan pengelolaan perikanan di desa tidak hanya sekadar mengelola dan memanfaatkan jangka pendek. Namun, mencakup kemanfaatan dan kemandirian bagi masyarakat desa jangka panjang dengan melibatkan saran dan prasarana serta peran aktif masyarakat/lembaga desa. Posisi strategis kawasan perdesaan menjadi pangkal pengalaman dan pembesaran pembangunan desa. Salah satunya dapat ditempuh melalui pengembangan desa berbasis perikanan dengan pemanfaatan dana desa. Dalam pengelolaan tersebut, perlu diperhatikan bagaimana kondisi yang ada saat ini (exsisting) serta kebijakan dan peraturan perundangan yang berkaitan dengan bidang perikanan.

Penelitian ini bertujuan untuk (1) mengetahui tingkat pemanfaatan bantuan pemerintah untuk desa berbasis perikanan, (2) mengetahui model pengelolaan kawasan perdesaan berbasis perikanan, (3) serta merumuskan bentuk kegiatan fasilitas pada kawasan perdesaan berbasis perikanan. Fokus penelitian ini di Kabupaten Gresik (Kecamatan Ujung Pangkah) dan Kabupaten Tuban (Kecamatan Bancar). Berdasarkan data statistik KKP 2014 dari Dinas Perikanan dan Kelautan Provinsi Jawa Timur, kedua wilayah tersebut memiliki jumlah potensi perikanan dan jumlah nelayan yang tergolong besar. Produksi sub sektor perikanan di Kabupaten Gresik sebesar 17.723,1 dengan nilai produksi sebesar 287.206.353 juta. Sedangkan, Kabupaten Tuban memiliki total produksi sub sektor perikanan sebesar $11.779,8$ dengan nilai produksi sebesar 64.538.472,9 juta.

Berdasarkan penjelasan di atas, maka muncul pertanyaan dasar yang menjadi acuan dalam penelitian ini: bagaimana kemanfataan bantuan pemerintah untuk desa yang berbasis perikanan? Bagaimana model pengelolaan kawasan perdesaan berbasis perikanan? Dan bagaimana bentuk kegiatan fasilitas pada desa yang berbasis perikanan? Untuk menjawab pertanyaan tersebut, dibutuhkan penelitian model strategi pengelolaan sumber dayaalam kawasan perdesaan berbasis perikanan, baik secara teknis maupun manajemen yang baik dan memadai. Dengan demikian, hasil penelitian dapat digunakan sebagai acuan bagi para pelaku pembangunan kawasasn perdesaan berbasis perikanan 
dalam mengelola dan memanfaatkan laut dan perikanan dengan melibatkan secara langsung peran masyarakat/lembaga desa.

\section{Metode Penelitian}

Penelitian ini menggunakan pendekatan kualitatif, dimana penggunaannya diharapkan mampu untuk menjelaskan hasil temuan data sehingga tidak menggunakan prosedur statistik atau metode kuatitatif (Anselm dan Juliet, 2009). Penentuan lokasi penelitian ini didasarkan dari aset kedua daerah yakni Kabupaten Gresik dan Tuban yang memiliki potensi perikanan cukup besar di Jawa Timur (Statistik KKP, 2014).

Penentuan informan yang dipakai dalam penelitian ini lebih kepada kapasitas untuk memberikan data yang tepat. Hingga dapat dibagi menjadi dua kategori, pertama adalah informan kunci, dimana darinya kita mendapatkan data-data penting dalam penelitian ini, yaitu dari masing-masing dinas berwenang di Wilayah Tuban dan Gresik. Nantinya akan ditambahkan data dari informan utama, yaitu para pelaku ekonomi yang dimaksudkan dalam riset ini, mulai dari nelayan, pedangan, hingga pada pemerhati kawasan ekonomi pesisir.

Pengumpulan data yang dilakukan melalui serangkaian metode yang biasa diterapkan pada penelitian sosial lainnya mulai dari obeservasi, wawancara dan dokumentasi. Pengamatan itu menjadi bagian penting, dimana akan bisa menambahkan data melalu fenomena-fenomena yang tertangkap panca indera dan tidak kita dapatkan dari wawancara maupun dokumentasi (Ali, 91-1993).

\section{Pengelolaan Sumber Daya Perikanan Berbasis Masyarakat}

Model pengelolaan ini sering disebut Community Based Fisheries Management (CBFM) yang merupakan model pendekatan pengelolaan sumber daya alam dalam bidang perikanan. Dalam pengelolaan ini, masyarakat lokal menjadi sentrum dalam pemberian wewenang, tanggung jawab, dan kesempatan untuk mengelola sumber daya perikanannya sendiri dengan terlebih dahulu mendefinisikan kebutuhan dan keinginan, tujuan serta aspirasinya (Nikijuluw, 2002). Dengan meletakkan pengetahuan dan kesadaran masyarakat, menempatkan masyarakat sebagai pusat pengambilan kebijakan berkelanjutan, model ini bertujuan untuk mengedepankan dan mengutamakan peran 
masyarakat dengan nilai-nilai lokalitas budaya sekitar dalam mengelola, mengembangkan, dan memanfaatkan potensi laut dan perikanan.

Adapun model pengelolaan ini dapat dikembangkan dengan beberapa cara: (1) pemerintah dan masyarakat harus mengakui praktik pengelolaan sumber daya perikanan yang selama ini dilakukan secara turun-menurun. Sehingga, kebijakan pemerintah dapat mengacu pada nilai-nilai lokalitas budaya sekitar yang tetap terjaga dan lestari; (2) pemerintah dan masyarakat menghidupkan kembali atau merevitalisasi adat dan budaya setempat dalam pengelolaan sumber daya perikanan; (3) pemerintah memberikan wewenang dan tanggung jawab kepada masyarakat untuk mengelola sepenuhnya. Ada juga model kerjasama yang dapat dibangun antara masing-masing stakeholder dalam pengelolahan sumberdaya perikanan. Salah satunya adalah co-management, hiraraki comanagement perikanan muncul karena adanya berbagai kemungkinan proses pengambilan keputusan yang melibatkan masyarakat lokal dan pemerintah (Alanis dkk, 2009)

Komunitas merupakan penyebutan lain yang bisa dipakai untuk menggantikan kata masyarakat dalam model pengelolaan ini. Masyarakat dalam pengertian statis menjadi suatu wadah dan wilayah dari kehidupan sekelompok orang yang ditandai oleh adanya hubungan sosial, nilai, serta norma-norma sosial. Dalam pengertian yang lebih dinamis, proses terbentuk melalui faktor-faktor pskologis dalam hubungan manusia, di dalamnya terkandung berbagai kepentingan, keinginan serta tujuan-tujuan bersifat fungsional. Herkovits dan Malinoski segala sesuatu yang terdapat dalam masyarakat ditentukan oleh adanya kebudayaan yang dimiliki oleh masyarakat (Soekanto, 1999).

\section{Pengelolaan Perikanan Berbasis Ekosistem}

Definisi Ecosystem Approach to Fisheries Management (EAFM) menurut FAO adalah pengelolaan perikanan yang mampu menampung dan menyeimbangkan berbagai kebutuhan dan keinginan masyarakat, dengan memperkirakan kebutuhan untuk generasi mendatang dalam memanfaatkan barang dan jasa yang disediakan oleh ekosistem kelautan. Pendekatan ini menjadi populer digunakan dalam pengelolaan perikanan (Kusnandar \& Mulyani, 2015). Pendekatan ini memperhitungkan pengetahuan dan ketidakpastian tentang keberlanjutan sumber daya, habitat, dan aspek stakeholder dalam ekosistem kelautan. Tujuan dari model ini adalah untuk menilai dan mengelola dampak 
ekologi, sosial, dan outcome yang terkait dengan kegiatan perikanan dalam kesatuan ekosistem (Fletcher, 2006).

Pengelolaan sumber daya melalui pendekatan EAFM ini menjadi salah satu model alternatif untuk pengelolaan ekosistem sumber daya ikan yang kompleks. Tujuannya adalah menjaga keutuhan dan kelestarian ekosistem laut. Model ini dapat menjadi alat monitoring ekosistem laut yang dilengkapi dengan indikator ekologi untuk mengukur perubahan ekosistem. Dengan demikian, perubahan ekosistem laut mudah untuk diketahui, manusia sebagai pusat ekosistemnya dapat dijelaskan perannya, sekaligus dapat memberikan tindakan cepat apabila terdapat kerusakan ekosistem. Sehingga, perencanaan dan pengelolaan laut model ini sangat relevan untuk strategi pembangunan berkelanjutan karena dapat menjamin proses ekologi di laut, keanekagaraman biologi laut, dan kelangsungan hidup untuk seluruh populasi spesies laut asli (Wiyono, 136-138, 2006).

Ada beberapa strategi yang dapat dikembangkan dalam pengelolaan perikanan berbasis ekosistem (Kasim,2017), yakni 1) perlunya pelepasan liaran ikan asli, 2) perlu adanya zonasi konservasi, 3) kegiatan domestikasi ikan asli di Balai Benih Ikan setempat, 4)rehabilitasi hutan, 5) pembatasan jumlah alat tangkap dan ukuran jaring. Bila kita memperhatikan, dari kedua model pengelolahan sumberdaya perikanan diatas, kita tidak akan bisa membandingkan mana yang lebih baik diantara keduanya. Partisipasi masyarakat dalam pengelolaan perikanan menjadi bagian penting bagaimana ekosistem perikanan tetap terjaga. Maka yang dibutuhkan bukan mencari yang terbaik, namun lebih kepada penggunaan kedua model pengelolahan tersebut dalam pemanfaatan sumberdaya perikanan yang ada.

\section{Kebijakan Pengelolaan Sumber Daya Kelautan dan Perikanan di Kabupaten Gresik dan Tuban}

Sumber daya perikanan merupakan salah satu aspek penting dalam perekonomian masyarakat perdesaan yang bermukim di pesisir. Yang dimaksud dengan kawasan perdesaan adalah kawasan yang mempunyai kegiatan utama pertanian termasuk pengelolaan sumber daya alam dengan susunan fungsi kawasan sebagai tempat permukiman perdesaan, pelayanan jasa pemerintahan, pelayanan sosial, dan kegiatan ekonomi (Perda Kab. Gresik, 8-2011). Nelayan merupakan bagian dari 
masyarakat perdesaan di mana segala hal yang berbau tradisional lebih dihargai dan dijadikan nilai-nilai pedoman bermasyarakat. Nelayan menjadi opsi yang tepat dalam memanfaatkan potensi sumber daya pesisir dan menjadi pekerjaan yang mudah dan banyak dikerjakan oleh masyarakat setempat.

Pada era pemerintahan Jokowi yang merupakan bagian dari Nawacita bahwasannya bidang perikanan merupakan salah satu potensi sumber daya alam Indonesia yang harus dikembangkan, menilai luas wilayah dua sepertiga bagian dari Indonesia adalah lautan yang menjadi sumber hasil keragaman hasil laut yang begitu melimpah. Kebijakan merupakan strategi yang dibuat pemerintah secara terstruktur dan sistematis berdasarkan permasalahan yang terjadi di masyarakat sebagai sebuah solusi dan perubahan dari apa yang bermanfaat bagi masyarakat itu sendiri. Kebijakan pemerintah menjadi begitu penting karena segala urusan dan permasalahan tentang aspek kehidupan masyarakat yang menyangkut hak milik negara harus diselesaikan dengan cara administrastif baik dalam pembangunannya ataupun strategi pengelolaan potensi sumber daya alamnya.

Kabupaten Gresik mengambil langkah dalam mengelola segala sumber daya yang ada dengan membuat Peraturan Daerah Kabupaten Gresik Nomor 8 Tahun 2011 tentang Rencana Tata Ruang Wilayah Tahun 2010-2030. Perda ini mengatur dan mengelola segala potensi dan aset sumber daya perikanan yang di Gresik. Salah satu upaya lainnya yang dilakukan oleh pemerintahan Kabupaten Gresik adalah dengan memberikan anggaran pengembangan potensi kawasan tersebut melalui dana desa di bawah naungan Badan Usaha Milik Desa (BUMDES).

Selain itu, terdapat aturan dan sumber hukum terkait dengan pengelolaan sumber daya perikanan, antara lain: (1) Peraturan Daerah Kabupaten Gresik Nomor 8 Tahun 2011 tentang Rencana Tata Ruang Wilayah Tahun 2010-2030; (2) Peraturan Daerah Kabupaten Gresik Nomor 8 Tahun 2011 Pasal 4 tentang Visi dan Misi Penataan Ruang; (3) Peraturan Daerah Kabupaten Gresik Nomor 8 Tahun 2011 BAB V Pasal 7; (4) Peraturan Daerah Kabupaten Gresik Nomor 8 Tahun 2011 Pasal 10 tentang Kebijakan dan Strategi Sistem Perdesaan; (5) Peraturan Daerah Kabupaten Gresik Nomor 8 Tahun 2011 Pasal 38 tentang Kebijakan dan Strategi Penetapan Fungsi Kawasan Pesisir dan Pulau-pulau kecil; (6) Peraturan Daerah Kabupaten Gresik Nomor 8 Tahun 2011 pasal 68 tentang Pemanfaatan kawasan peruntukan perikanan. 
Dalam aturan tersebut terlihat bahwasa kebijakan berupa pembuatan Peraturan Daerah Kabupaten Gresik Nomor 8 Tahun 2011 merupakan salah satu upaya yang dilakukan pemerintah untuk mengelola potensi perikanan yang ada di Kabupaten Gresik. Adapun penjelasan terhadap prospek pengembangan yang dilakukan terhadap pengelolaan potensi perikanan adalah dengan melihat potensi wilayah itu sendiri, yaitu Kabupaten Gresik memiliki kawasan pesisir dan pulau kecil, yaitu Pulau Bawean. Potensi kawasan pesisir dan pulau kecil di Kabupaten Gresik pada perikanan yang besar, baik perikanan tangkap maupun perikanan budidaya (tambak) dengan jenis komoditi yang cukup bervariasi yaitu berupa tiram/kerang, ikan kerapu, teripang, dan rumput laut. Selain itu, kebijakan yang merupakan usaha lain dari pemerintah untuk masyarakat Perdesaan di Kabupaten Gresik khususnya daerah pesisir dengan potensi perikanan yang aktif dengan aktivitas yang tinggi guna memberikan kemanfaatan bagi masyarakat perdesaaan atau pesisir dalam rangka pengelolaan potensi perikanan adalah dengan mengucurkan Anggaran pengembangan melalui dana desa di bawah naungan Badan Usaha Milik Desa (BUMDES).

Kabupaten Tuban merupakan salah satu wilayah yang berada di pantai utara pulau jawa. Mengenal Kabupaten Tuban juga mengenalkan kita kepada potensi perikanan daerah pesisir pantai utara pulau jawa. Potensi ikan di Kabupaten Tuban sama halnya dengan potensi-potensi lain di daerah pesisir Pulau Jawa, seperti Lamongan, Gresik dan Madura. Potensi perikanan dan gerak perekonomian wilayah pesisir pulau jawa memang sudah tidak dapat diragukan lagi. Hasil komoditas lautnya yang sudah terkenal dan menjadi hasil unggulan serta penyokong utama kebutuhan rumah tangga masyarakat di Desa Bulumeduro, Kabupaten Tuban. Desa Bulumeduro merupakan salah satu desa yang ada di Kabupaten Tuban yang perekonomiannya didukung atas hasil laut. Adapun mayoritas mata pencaharian masyarakat Desa Bulumeduro, Kabupaten Gresik adalah nelayan, pedagang (pengepul) dan pengolah hasil komoditas laut.

Dalam setiap potensi daerah yang dimilki pemerintah secara langsung berkewajiban menjaga dan mengembangkan potensi sumber daya dengan baik. Seperti potensi perikanan yang cukup mendukung perekonomian masyarakat Kabupaten Tuban. Pemerintah secara transparan berkewajiban mendukung sepenuhnya atas pengembangan potensi daerah yang ada dengan dana yang sudah disediakan pemerintah pusat. melalui 
adanya otonomi daerah pemerintah Kabupaten Tuban dapat dengan bebas mengatur dengan metode seperti apa ataupun kebijakan seperti apa yang harus di buat guna memajukan potensi perikanan yang ada di Kabupaten Tuban.

Kabupaten Tuban dalam penanganan pengelolaan sumber daya perikanan tidak jauh berbeda dengan Kabupaten Gresik. Adanya otonomi daerah pemerintah Kabupaten Tuban dapat dengan bebas mengatur dengan metode seperti apa ataupun kebijakan seperti apa yang harus di buat guna memajukan potensi perikanan yang ada di Kabupaten Tuban. Adapun program dan kebijakan yang dibuat pemerintah sebgaai upaya peningkatan potensi perikanan di Kabupaten Tuban khususnya program untuk budidaya perikanan tangkap adalah: (1) Pengembangan sarana prasarana kawasan peruntukan perikanan tangkap; (2) Pembangunan pangkalanpendaratan ikan; (3) Pelestarian dan pengembangan ekosistim kawasan peruntukan perikanan tangkap; (4) Penggunaaan alat tangkap ikan yang ramah lingkungan; (5) Peningkatan produktivitas hasil perikanan tangkap; (6) Pengembangan pelabuhan pendaratan ikan (PPI) Bulu dan Karangagung; (7) Pengembangan kemitraan antara nelayan dengan pihak terkait.

Adapun usaha lain yang dilakukan pemerintah guna meningkatkan usaha perkembangan pengelolahan potensi perikanan yang ada di Desa Bulumeduro, Kabupaten Tuban adalah dengan melalui Badan Usaha Milik Desa (BUMDES). Proses pembentukan BUMDES Bersama masih pada tahap perancanaan program kerja. Rencana awal BUMDES bersama ini nantinya akan di pusatkan di Desa Bulumeduro. Gambaran dari rencana kerja yang dibentuk nantinya adalah mempunyai usaha simpan pinjam, kios desa dan kios saprodi lainnya. Namun rencana tersebut masih belum final karena masih terkendala koordinasi antar pengurus dan belum jelasnya sumber pembiayaan dan system kerja antara 4 desa tersebut. BUMDES yang terbentuk di Desa Bulumeduro adalah BUMDES “Inti Mina Tani” dengan tiga unit usaha yakni :

- HIPAM (himpunan pengguna air minum)

HIPAM di bentuk pada tahun 2011 dari bantuan PNPM mandiri stelah itu pengelolaannya dialihkan untuk BUMDES Desa pada tahun 2015. Sampai pada saat ini HIPAM masih berlangsung. Untuk pembayaran dilakukan setiap 2 minggu sekali.

- Agen 46 (pembayaran rekening rekening listrik dll) 
Agen 46 merupakan bagian dari program Desa yang dialihkan untuk BUMDES pada tahun 2015, salah satu tugas dari agen 46 ini adalah penyaluran bantuan $\mathrm{PKH}$ dan dapat pembayaran rekening-rekening listrik.

- Kios desa ( masih dalam tahap rencana untuk penjualan produk hasil olahan perikanan)

Untuk kios desa baru selesai pada tahap pembangunan kios, pembangunan kios didanai dari dana desa. Rencananya kios tersebut nantinya akan digunakan untuk penjualan produk perikanan di Desa Bulumeduro, rencana ini masih pada tahap penentuan teknis untuk menarik konsumen agar bisa berhenti di lokasi kios untuk bebelanja oleh - oleh. Adapun BUMDES “Inti Mina” yang ada di Desa Bulumeduro ini bermitra dengan Bank Negara Indonesia (BNI). Adapun kerja sama yang dilakukan dengan BNI adalah dalam penyaluran bantuan atau pembayaran rekening listrik. Dalam setiap usaha yang dilakukan selalu memiliki kendala dalam pelaksanaanya, adapun kendala yang dihadapi adalah :

1. Kurang aktifnya pengurus BUMDES sehingga kepengurusan BUMDES masih dalam intruksi kepala desa atau perangkat setempat.

2. Koordinasi antara pengurus untuk membahas program kerja selanjutnya (kos desa) masih terkendala waktu pertemuan yang pas, sehingga mengakibatkan molornya program berjalan.

3. Pada usaha HIPAM, susahnya untuk di lakukan penarikan iuran biaya pemakaian air karena masyarakat masih beranggapan bahwa HIPAM tersebut meruapakan dana dari Negara, sehingga beranggapan bahwa yang pakai adalah biaya dari Negara.

\section{Komparasi Pengelolaan Sumber Daya Perikanan Di Kabupaten Gresik Dan}

\section{Tuban}

Dalam penelitian ini akan mencoba mengomparasikan dua kabupaten di Jawa Timur, yaitu: Gresik dan Tuban. Dengan mengambil sample di Kecamatan Ujung Pangkah di Kabupaten Gresik serta Kecamatan Bancar di Kabupaten Tuban. Dengan menempatkan tiga (3) subjek ekonomi yang mana terdapat relasi aktivitas dalam proses pengelolaan dan pemanfaatan sumber daya alam kelautan dan perikanan di masingmasing kabupaten, yakni: produksi (nelayan), distribusi (pedagang), dan konsumen 
(pengelola). Oleh karena itu, hasil penelitian dapat menjelaskan bagaimana model masyarakat dalam mengelola dan memanfaatkan sumberd daya alasan di kawasan yang berbasis perikanan. Dan, keterlibatan pemerintah dalam memberikan wewenang dan tanggung jawab terhadap masyarakat untuk terlibat langsung dalam pengelolaan dan pemanfaatan sumber daya alam melalui bantuan dan kebijakan yang ada.

\section{Komoditas Nelayan}

Hasil komoditas laut para nelayan semuanya bergantung pada keadaan musim di mana musim paceklik jumlah hasil laut yang didapat lebih sedikit dibandingan dengan musim puncak. Perbandingan hasil laut pada musim paceklik dengan musim puncak adalah 1:3. Pada musim paceklik, para nelayan di Ujung Pangkah banyak menganggur dan membenahi perlengkapan penangkap iikan. Hal ini karena, hasil pengakapan sangat kecil dan modal penangkapan ikan jauh lebih besar daripada hasil tangkapan. Waktu para nelayan pun semakin tidak menentu: (1) Operasi kapal musim paceklik hanya \pm 15 kali/bulan; (2) Operasi kapal musim sedang maksimal 24 kali/bulan; (3) Operasi kapal musim puncak hanya $\pm 26 \mathrm{kali} / \mathrm{bulan}$.

Pada musim paceklik, para nelayan yang ada di Desa Bulumeduro pergi berlayar sebanyak kurang lebih 20 kali dalam sebulan sama seperti pada musim puncak nelayan di Desa Bulumeduro bisa lebih melakukan pelayaran 20 kali dalam sebulan. Tindakan lanjutan yang dilakukan oleh nelayan guna menyiasati situasi hasil penangkapan yang tidak mampu mencukupi kebutuhan adalah dengan mengendalikan pasokan berikutnya dengan mengakumulasikan waktu berlayar yang dirasa cukup mampu memenuhi kebutuhan hasil laut. Aktivitas efektif berlayar yang dilakukan nelayan di Di Desa Bulumeduro dimulai pukul 05.00-12.00 WIB sekitar 7 jam kegiatan efektif dalam sehari. Selain musim yang menjadi kendala dalam berlayar adalah cara managemen keuangan hasil berlayar juga tidak menentu belum lagi dengan biaya operasional disbanding dengan hasil laut yang didapat yang tidak mampu menutupi.

Bentuk modal yang berasal dari nelayan di Ujung Pangkah adalah bensin setiap kali berlayar yang merupakan bahan bakar kapal yang harus dipenuhi, selain itu juga perlengkapan seperti jaring, box ikan, dan kapal yang setiap waktu memerlukan maintenance agar supaya dapat selalu dimanfaatkan dan digunakan sebagaimana fungsinya. Untuk biaya perawatan seperti kapal harus memakan biaya sebesar 1 (satu) 
juta/tahun. selain itu juga biaya operasional yang harus ditanggung setiap kali trip (berlayar) berupa:

1. Bahan bakar (bensin) : 10 liter/trip

2. Anak buah kapal (ABK) : 2 orang

3. Konsumsi : Pribadi

4. Oli mesin kapal : 5 liter/tahun

5. Retribusi : 10.000/bulan, 10 lembar/trip

Biaya di atas belum termasuk angsuran bulanan atau uang sewa setiap kali berlayar. Dengan mayoritas nelayan yang belum memiliki kapal sendiri dan mash banyak yang menyesa serta membeli secara mengangsur. Hal ini menjadi kendala ketika biaya operasional ditambah dengan uang angsuran dan sewa tidak sebanding dengan tangkapan hasil laut. Adapun biaya angsuran yang harus ditanggung nelayan sebesar:

1. Kapal besar < 3GT memiliki nilai Angsuran dan sewa biaya sebesar 100.000/200.000/penangkapan.

2. Kapal besar 5 GT memiliki nilai angsuran dan sewa biaya sebesar 300.000/400.000/pengangkapan.

Jika dibandingkan dengan nelayan di Bulumeduro, biaya operasional kapal yang harus ditanggung jauh lebih besar daripada nelayan di Ujung Pangkah. Adapun biaya operasional tersebut, antara lain:

1. Bahan bakar : 7-8 liter/trip

2. Biaya perawatan kapal : Rp 1.000.000-6.000.000/tahun (3GT-5GT)

3. Biaya oli : 6 liter/tahun

4. Pembagian dengan ABK : 6 orang

5. Konsumsi : kondisional, bawa sendiri

6. Penyimpanan : Box dan es balok 0,25 balok/trip

7. Retribusi/pajak : Rp 15.000,00/bulan

Selain kebutuhan operasional yang dirasa memakan hasil tangkapan, ada hal lain yang utama adalah kapal yang digunakan berlayar. Kebutuhan berlayar kapal nelayan di Bulumeduro cukup besar mengingat kapal-kapal tersebut merupakan kepemilikan pribadi. Konteks finansial nelayan di Bulumeduro sangat berbeda jauh dengan nelayan di Ujung Pangkah. Kebanyakan nelayan Bulumeduro memiliki kemadirian finasial yang cukup sehingga banyak nelayan yang punya kapal sendiri. Untuk kepemilikan kapal 
sendiri, para nelayan mesti mengeluarkan modal awal sebesar 15 juta/kapal dengan ukuran 3 GT, sedangkan kapal ukuran 15 GT dipatok dengan harga 200 juta/kapal: semakin besar ukuran GT kapal maka biaya untuk maintanace juga semakin besar.

Para nelayan Ujung Pangkah dan Bulumeduro sama-sama tidak memiliki pemahaman atas BUMDES terutama di Bulumeduro tidak begitu mengerti dan paham fungsi dan tujuan dari dibentuknya BUMDES iitu sendiri. Pada umumnya, para nelayan tidak bermitra dengan BUMDES yang telah dibentuk pemerintah setempat. Dan, para nelayan seolah tidak merasakan dan tersentuh bantuan sama sekali dengan adanya BUMDES itu sendiri. Terutama nelayan Ujung Pangkah ketika disurvei dengan syarat memiliki mata pencaharian nelayan, 2 (dua) dari 5 (lima) sampel warga tidak memahami dan mengerti apa yang dimaksud BUMDES. Dengan demikian, keberadaan BUMDES bagi para nelayan belum menyentuh dan menjadi bahan evaluasi bagi pemerintah setempat agar para nelayan mendapat manfaat dari keberadaan BUMDES yang diperuntukkan untuk membantu aktivitas para nelayan.

Berbeda dengan BUMDES, melalui Dinas Kelautan dan Perikanan yang ada di Kabupaten Tuban, masyarakat Bulumeduro kurang lebih sedikit mendapatkan perhatian seperti mendapatkan box ikan, fish finder dan beberapa alat melaut lainnya. Adapun kegiatan yang dilakukan sesuai dengan program strategi kabupaten Tuban sendiri yaitu salah satunya adalah dengan melakukan sosialisasi DKP kabupaten dan Provinsi tentang cara penangkapan ikan. Hal ini dirasa cukup bermanfaat nelayan, setidaknya pemerintah tidak sepenuhnya lepas tangan akan kemandirian perekonomian masyarakatnya khususnya di daerah pesisir. Walaupun demikian bantuan yang diberikan tidak cukup merata dan bermanfaat secara signifikan bagi masyarakat nelayan yang ada di Desa Bulumeduro.

Jika dibandingkan dengan nelayan Bulumeduro, yang sama-sama tidak memahami BUMDES tetapi mendapat bantuan dari Dinas Kelautan dan Perikanan setempat, para nelayan Ujung Pangkah hampir tidak mendapat bantuan dari pemerintah. Pemerintah tidak cukup memahami alat-alat yang dimiliki nelayan yang sebenarnya tidak cukup baik dan memadai dalam melakukan penangkapan. Menurut keterangan nelayan, pemerintah hanya memberikan bantuan berupa kompresor, pelampung, dan beberapa mesin kapal. Sehingga, bantuan tersebut tidak cukup signifikan membantu para nelayan di Ujung Pangkah. Dengan demikian, pemerintah harus memperhatikan 
nasib dan kondisi para nelayan di Ujung Pangkah yang sangat mengharapkan bantuan dari pemerintah setempat. Bantuan bagi mereka sangat berarti dan penting, misalnya, mengurangi biaya produksi, perlengkapan nelayan, maupun bantuan finasial atau bantuan kredit usaha. Bantuan kredit ini dimaksudkan untuk menunjang para nelayan sebagai bentuk pinjaman modal baik untuk menanggung biaya operasional atau biaya produksi. Sehingga, perekonomian nelayan bisa sedikit terbantu.

\section{Pengelolaan Pedagang}

Pedagang merupakan lakon utama dalam mengendalikan jumlah bahan baku dagangan dan nilai jual bahan baku tersebut. seperti dalam hukum permintaan ekonomi bahwasanya jika bahan baku melimpah, permintaan sedikit maka harga akan turun. Hal ini juga berlaku bagi para pedagang hasil laut yang ada di Kecamatan Ujung Pangkah Kabupaten Gresik dan pedagang di Desa Bulumeduro Kabupaten Tuban. Musim menjadi penyebab utama ketidakstabilan hasil laut sehingga juga berdampak pada jumlah bahan baku pedagang. Sama halnya dengan nelayan jika pada musim paceklik perolehan hasil laut menurun, maka bahan baku pedagang juga akan menurun. Sehingga antara ketersediaan bahan baku dengan kebutuhan dan permintaan menjadi tidak seimbang dan mempengaruhi harga jual dan harga beli bahan ataupun hasil laut yang ada di pasar.

Dalam strategi peningkatan potensi perikanan yang ditawarkan pemerintah Kabupaten kepada masyarakat dalam bentuk kebijakan dan pengaturan dasar hukum dirasa kurang mampu mengayomi dan berdampak signifikan terhadap masyarakat. Hal ini dibuktikan dengan adanya BUMDES di setiap desa terpilih di Kabupaten Gresik. Masyarakat Kabupaten Gresik, terutama di Kecamatan Ujung Pangkah hampir tidak mengetahui atau mengerti lembaga yang dibentuk pemerintah untuk membantu kesejahteraan masyarakat pedesaan. Hal yang sama dialami masyarakat Bulumeduro. Mereka hanya mengenal BUMDES tanpa mengerti fungsi dan kemanfaatan secara tertulis dibentuknya BUMDES. Sekalipun keberadaan BUMDES Bulumeduro memiliki relasi dengan salah satu bank milik pemerintah. Namun, soal bantuan pemerintah berupa box pendingin, basket ikan, dan berbagai perlengkapan lain hanya sedikit dirasakan oleh para pedagang. 
Ketika menghadapi musim paceklik, metode pengelolaan yang dilakukan pedagang di Kabupaten Gresik hanya mendistribusikan bahan baku kepada pengepul saja. Dengan sistem transaksi secara tunai/cash dirasa sangat transaparan dalam proses transaksi yang dilakukan. Selain itu sebagian pedagang hanya menunggu pengepul untuk datang mengambil bahan baku kerumah sehingga alur distribusi menjadi lebih sederhana. Aktivitas yang dilakukan oleh pedangan yang ada di Kecamatan Ujung Pangkah berlangsung di mulai pukul 08.00 WIB hingga pukul 16.00 WIB. Sehingga aktivitas jual beli dilaksanakan hanya dalam waktu 8 jam. Baik aktivitas antara pedagang dan pengepul, ataupun pedagang dengan nelayan. Berbeda dengan pedagang di Bulumeduro Kabupaten Tuban yang melakukan transaksi secara kreidt dan dibayar di muka. Hal ini dilakukan karena setiap pedagang memiliki pembeli tetap atau disebut sistem langganan. Biasanya perbandingan harga ikan musim paceklik yaitu Rp. 28.00030.000/ kilogram untuk kualitas 1 (satu) atau dalam kualitas baik. Sedangkan pada musim puncak harga ikan dengan kualitas 1 (satu) dibanderol dengan harga Rp. 24.00025.000/ kilogram.

\section{Usaha Pengolah}

Usaha pengolah yang ada di Kecamatan Ujung Pangkah, Kabupaten Gresik mendapatkan bahan olahan berupa berbagai macam ikan dan hasil laut dari para pedagang dan nelayan. Para pengolah membeli bahan olahan di pelelangan ikan dan pasar lokal. Usaha pengolahan ikan yang ada yang ada di Kecamatan Ujung Pangkah, Kabupaten Gresik berupa pengolahan ikan dan kerang. Adapun pengolah yang yang mayoritas mengelola bahan olahan berupa kerang, antara: kerang balok; kerang dara; kerang putih, dan kerang kunyit. Usaha pengolahan sebagian besar didistribusikan untuk dijual ke Hotel dan Restoran yang ada disekitar Kabupaten Gresik dan wilayah jangkauan terdekat. Sedangkan, pengolah di Bulumeduro lebih banyak bahan olahan sepertii ikan tongkol, cumi-cumi, ikan pari, dan tengiri yang semuanya mayoritas hasil tangkapan nelayan di sana. Jenis-jenis ikan yang diolah sebagian besar pengolah Bulumeduro merupakan ikan utuh atau ikan yang berkualitas 1 (satu). Meski demikian, pengolah di dua wilayah tersebut juga bergantung pada hasil tangkap nelayan apalagi pada musim paceklik yang hasilnya bsa sangat menurun dan memengaruhi bahan olahan. 
Kebutuhan akan hasil laut di Kabupaten Gresik menjadi sangat penting. Kebutuhan yang dapat disediakan para pengolah setiap minggu adalah sebesar 500-1000 kilogram. Sedangkan, pengolah di Bulumeduro Kabupaten Tuban memiliki kebutuhan pasokan olahan kisaran harga pada musim paceklik pada umumya dibanderol 20.00030.000/kilogram, sedangkan pada musim puncak harga kisaran 15.000-20.000/kilogram tergantung jenis komoditas ikan yang diperlukan.pada umumnya para pengolah yang ada di Desa Bulumeduro mengambil atau membeli ikan di TPI Bulu. Sebagian hanya membeli ikan kepada pedagang ikan langsung dengan kondisi ikan yang masih fresh, bersih dan layak konsumsi.

Adapun aktivitas aktif yang setiap hari dilakukan para pengolah selama 7 jam dalam sehari, di mulai pukul 06.00-13.00 WIB. Musim menjadi kendala utama dalam alur pengolahan komoditas hasil laut di Kecamatan Ujung Pangkah, Kabupaten Gresik. Kendala lain yang dihadapi pengolah adalah transportasi yang ada tidak memadai, jarak dan trasportasi, di mana jarak lumayan jauh yang harus ditempuh untuk mendapatkan ikan target dan tranportasi yang digunakan hanya sepeda motor tidak bisa mengangkut banyak dan harus dua sampai 4 kali pengankutan. Ketika musim paceklik tiba jika stok bahan olahan tidak mencukupi maka kebanyakan pengolah memutuskan untuk libur. Berbeda dengan pengolah Bulumeduro, selain memiliki waku efektif yang tidak menentu, yakni aktivitas yang di mulai pada pukul 08.30-18.00 WIB tergantung pada metode pengelolahan, metode pengasinan atau metode masakan siap saji, para pengolah kini memasarkan olahan mereka secara online yang dirasa sangat menguntungkan. Namun, ini tidak dilakukan semua pengolah karena ada beberapa pengolah yang menjualnya ke pasar lokal dan pusat perbelanjaan toko oleh-oleh.

Keberadaan BUMDES sangat membantu pengolah dalam memanfaatkan sumber daya perikanan, terutama pengolah Bulumeduro mesikupun tidak semua mendapat manfaatnya. Para pengolah hampur seluruhnya mengenal BUMDES dan beberapa pengolah juga turut menjad pengurus BUMBES itu sendiri. BUMDES Bulumeduro bermitra dengan Agen 46 yang bekerja sama dengan Bank Nasional Indonesia (BNI) dan mendapat bantuan hibah program HIPAM. Selain itu,pemerintahjuga memberika bantuan secara fisik seperti box pendingin, basket, timbangan, wajan, pisau, dan gunting serta peralatang pengolahan lainnya. Semua bantuan tersebut hingga saat ini sangat dirasakan manfaatnya oleh para pengolah. Hal ini berbanding terbalik dengan para 
pengolah di Ujung Pangkah Kabupaten Gresik. Masyarakat pesisir khususnya pengolah hanya mengetahui adanya BUMDES itu sendiri namun tidak ikut andil dalam pengelolahan BUMDES. BUMDES dinilai sebuah lembaga yang mati suri. BUMDES yang ada di Kecamatan Ujung Pangkah, Kabupaten Gresik ini baru saja dibuat namun tidak ada gebrakan dalam pelaksanaannya untuk membantu atau memberikan solusi kepada masyarakat pesisir. Pemerintah harus lebih jelih dalam melakukan fungsinya kembali sebagai pengawas dalam kebijakan yang dibuat. Sehingga manfaat atas kebijakan atau keberadaan BUMDES ini benar-benar memberikan manfaat dan perubahan bagi masyarakat.

\section{Kesimpulan}

Bantuan pemerintah untuk Kabupaten Gresik dirasa masih sangat kurang bermanfaat dan kurang dapat dirasakan para nelayan, pedagang dan pengolah di wilayah pesisir Kecamatan Ujung Pangkah, Kabupaten Gresik. Sedangkan, masyarakat pesisir Kabupaten Tuban dirasa sudah sangat cukup bermanfaat, dengan program-program sosialisasi hingga program HIPAM dan Agen 46 yang sangat dirasakan masyarakat khususnya para pengolah. Lembaga bentukan pemerintah yaitu BUMDES dirasa sangat kurang sekali dampaknya dalam membantu masyarakat yang ada di Kabupaten Gresik dan Kabupaten Tuban baik secara fungsional dan tujuan dalam pembentukan lembaga BUMDES. Fasilitas yang diberikan pemerintah di rasa tidak cukup memadai dan merata bantuan yang diberikan hanya berupa peralatan dan kelengkapan bagi nelayan saja. Fasilitas bagi pedagang dan pengolah dirasa kurang memadai sehingga banyak perlunya perbaikan dan peninjauan ulang oleh pemerintah. Selain itu, bantuan secara finansial masih perlu banyak ditingkatkan menilik dari kendala utama yang dihadapi para nelayan, pedagang dan pengolah adalah musim yang tidak menentu sehingga ketika pasokan hasil komoditas perikanan yang tidak stabil masyarakat lebih memilih untuk menganggur dan kurang efektif sehingga menganggu perputaran perekonomian masyarakat dan menurunnya pendapatan masyarakat itu sendiri. 


\section{Referensi}

Ali, Muhammad. 1993. Strategi Penelitian Pendidikan. Bandung: Angkasa

Alanis Muluk, Putri E Seprianti, Haliawan Prilia, 2009, "Pengelolahan Sumberdaya Perikanan Berbasis Masyarakat (PSPBM) Melalui Model Co-Management Perikanan” Jurnal Ekonomi Pembangunan

Anselm S. dan Juliet C, 2009, Dasar-dasar Penelitian Kualitatif, Yogyakarta:Pustaka Belajar, hal. 4

Fletcher WJ. 2006, "Frameworks for managing marine resources in Australia through ecosystem approaches: do they fit together and are they useful?" Bulletin of Marine Science.

Kasim Kamaluddin, Prianto Eko, Triharyuni Setiya, 2017, "Pengelolahan Sumberdaya Perikanan Melalui Pendekatan Ekosistem di Paparan Banjiran Giak Siak Kecil”, Jurnal Kebijakan Perikanan Indonesia.

Keputusan Menteri Kelautan dan Perikanan Nomor 45 Tahun 2011 Tentang Estimasi Potensi Sumber Daya Ikan di Wilayah Pengelolaan Perikanan Negara Republik Indonesia

Kementerian PPN/Bappenas. 2014. Kajian Strategi Pengelolaan Perikanan Berkelanjutan Tahun 2014. Jakarta

Kusnandar \&Mulyani, S. (2015). Strategi pengelolaan sumberdaya perikanan berbasis ekosistem. OSEATEK, 9.Lampiran Indikasi Program 5 (lima) Tahunan Kabupaten Tuban.

Muhammad Ali, 1993, Strategi Penelitian Pendidikan, Bandung: Angkasa

Nikijuluw, V.P.H, 2002."Rezim Pengelolaan Sumberdaya Perikanan". PT. Pustaka Cidesindo. Jakarta.

Peraturan Daerah Kabupaten Gresik Nomor 8 Tahun 2011 tentang Pengelolaan Tata Ruang wilayah Kabupaten Gresik Tahun 2010-2030. Bab I Nomor 20.

Soekanto, Soejono, 1999, “Pokok-Pokok Sosiologi Hukum”, Jakarta, Rajawali

Statistik KKP 2014, Dinas Perikanan dan Kelautan Jawa Timur.

Wiyono ES. 2006. Analisis Kebijakan Perikanan Pantai di Indonesia. Dalam MFA Sondita, editor. Kumpulan Pemikiran Tentang Teknologi Perikanan Tangkap yang Bertanggungjawab. Bogor: PSP FPIK-IPB. 